\title{
The Correlation Between Self-Control and Cyberbullying at Private High School X in Bogor
}

\section{Nadzifah Fiddiana*, and Aji Bagus Priyambodo}

Psikologi, Universitas Negeri Malang, Malang, Indonesia

ORCID

Nadzifah Fiddiana; https://orcid.org/0000-0002-6713-7373

\begin{abstract}
Teenagers try to develop their identity. Adolescents who fail to realize their identity may develop problematic behaviors. Technological developments have had a major impact, such as the emergence of new forms of bullying, namely cyberbullying carried out through electronic media. Juvenile delinquency such as cyberbullying can be influenced by several factors, including the lack of individual self-control. Individuals who have good self-control should be able to regulate their behavior in a more positive direction. This study aimed to determine whether there is a correlation between self-control and cyberbullying in Private High School $X$ in Bogor. The study sample consisted of 95 students recruited through purposive sampling. The study employed

a quantitative method with a Cyberbullying Scale comprised of 26 items with a 0.873 reliability, and a Self-Control Scale comprised of 22 items with a 0.853 reliability. Validity was evaluated by testing content with expert lecturers. Data were analyzed using the product-moment correlation technique. The study results produced an $r$ of $-0.465(p<0.05)$, indicating a significant negative correlation between self-control and cyberbullying in students at Private High School $X$ in Bogor.
\end{abstract}

Corresponding Author: Nadzifah Fiddiana; email: nadzifah.fiddiana.1708116@stundents. um.ac.id

\section{Dates}

Published 28 January 2022

Publishing services provided by Knowledge E

(c) Nadzifah Fiddiana, and Aji Bagus Priyambodo. This article is distributed under the terms of the Creative Commons

Attribution License, which permits unrestricted use and redistribution provided that the original author and source are credited

Selection and Peer-review unde the responsibility of the ICoPsy Conference Committee.

\section{G OPEN ACCESS}

Keywords: cyberbullying, self-control, teenagers

\section{Introduction}

Adolescence is one of the most critical periods in the span of human life. Adolescence is a period of developmental transition from childhood to adulthood that involves cognitive, biological, and socio-emotional changes [1]. Teenagers have a dynamic character, love to hang out, communicate, and socialize. Steinberg [2] divides adolescence into three categories, i.e., early adolescence (11-14 years), middle adolescence (15-18 years), and late adolescence (18-21 years). On average, high school students are 15-18 years old who fall into the middle teen category.

At this time, adolescents will try to get emotional freedom, look for values that suit themselves, and explore themselves in search of self-identity. The impact of adolescents failing to realize their identity is that they will develop problematic behavior that is considered deviant, shut themselves off from the social environment, and commit crimes [3]. 
One of the behavioral deviations in adolescents that have recently received attention from the wider community is bullying. Bullying is an act of intimidation carried out by physically and mentally strong parties to weak parties in the form of physical, verbal, and relational violence [4].

The era of the industrial revolution 4.0 has had a significant impact on technological developments. One technology that is rapidly growing is the internet. Based on a survey conducted by the Association of Indonesian Internet Service Providers (APJII) in 2020 [5], internet users in Indonesia reached $73.7 \%$. The majority of internet users aged 10 14 years as much as 8.31\%, followed by those aged $15-19$ years as much as $8.29 \%$. Meanwhile, $24.7 \%$ use the internet to open social media.

The use of social media can bring both positive and negative sides. According to Fitri [6], the positive side of social media is that it provides easy access to learning media and wider friendships on social networks. Nevertheless, the negative side can make individuals addicted to social media and experience harassment and intimidation called cyberbullying [7]. It is supported by the APJII survey [5], in which $49 \%$ of internet users in Indonesia have experienced cyberbullying on social media. Cyberbullying is a modern form of bullying carried out through electronic media [8].

The phenomenon of cyberbullying behavior that occurs among teenagers is increasingly real. Reporting from the kompas.com page [9], the Cilacap Police named four suspects in the bullying case who uploaded a video of bullying on his Instagram account. It is known that the victim of this bullying and cyberbullying behavior is a school friend and is still in junior high school. Another phenomenon in Bekasi Regency, quoted from Kompas.com [10], the bullying started from social media where victims and perpetrators quarreled triggered by mocking each other on social media (cyberbullying behavior). Feeling disapproved, the perpetrator invited the victim to meet in person, and at that time, the perpetrator was bullying and videotaped his action, which was then distributed on social media (cyberbullying behavior). The latest case from Bogor Regency was reported from the beritasatu.com page [11]. Cyberbullying was carried out on social media by uploading videos of bullying. Bogor Police Chief AKBP Harun confirmed this case. This case was resolved amicably because the perpetrator's motive was said to be excessively joking.

Juvenile delinquency is a social problem that shows unhealthy development, especially in the environment of people who live in big cities [12]. Research conducted by Malihah and Alfiasari [13] regarding cyberbullying behavior in junior high school students in Bogor City found that two out of five teenagers had cyberbullying behavior above the average of other teenagers. The level of cyberbullying behavior remained high. 
In March 2021, the author conducted interviews with five students at a private high school in Bogor City doing online learning. Information was obtained that these five teenagers had done cyberbullying behavior on social media and witnessed their schoolmates doing cyberbullying behavior on social media. From these phenomena, it can be seen that cyberbullying behavior has spread among teenagers. Among them are provoking friends to dislike other people, insulting and mocking with rude, disrespectful, sarcastic language, doing intense spam aimed at making the target person nervous, spreading the ugliness of friends, and stalking, which aims to find out the badness of friends and spreading other people's private photos whose purpose is to embarrass others.

According to Willard [14], cyberbullying behavior is the cruel treatment of others by sending or posting harmful or cruel texts or images using the internet or other digital technology devices. Willard [14] categorizes seven forms of cyberbullying: flaming, harassment, denigration, impersonation, outing and trickery, exclusion, and cyberstalking.

The impact of cyberbullying behavior is greater than bullying behavior because it leaves digital traces such as writing, photos, and videos (dslawfirm.com). According to Syah \& Hermawati [15], bullies (including cyberbullying) have a high risk of being involved in juvenile delinquency, crime, and alcohol abuse. According to Rudi [16], several individual motivations for cyberbullying can be anger, hurt, revenge, or frustration. According to Pandie and Weismann [17], what makes teens become perpetrators of cyberbullying is intentional because the perpetrators may feel hurt or angry because of the communication sent on social media.

Disa (in Satalina,[18]) mentions that several factors can influence cyberbullying behavior in adolescents, namely personality characteristics, traditional bullying, the perpetrator's perception of the victim, strain, and interaction of parents with children. Every individual doing cyberbullying is influenced by factors that influence from within, such as self-control [19]. According to Santrock [1] , one of the factors that influence juvenile delinquency is self-control. Dewi, Suryani, and Sriati [20] revealed that five factors influence cyberbullying in adolescents: individuals, families, friends, schools, and use of social media. Individual factors are expressed as predictors of factors, including the experience of violence, perception, gender, age, self-control/self-control, and use of addictive substances.

Self-control is a simple psychological variable because it includes three different concepts about the ability to control oneself: the individual's ability to modify behavior, 
manages information, and choose an action based on a belief [21]. According to Averill [21], aspects of self-control are behavioral control, cognitive control, and decision control.

In June 2021, the author conducted interviews with the Counseling Guidance (BK) teacher and the Deputy Principal for Public Relations (Public Relations Vice-Chairman) at Private School $\mathrm{X}$ related to the condition of students at the school. The BK teacher informed the students about the students' problems, such as bullying among students, confusion in choosing majors, and difficulties in overcoming online learning. Then the Public Relations Vice-Chairman revealed that the school routinely held character education for students. Character education aims to become individuals with integrity, making themselves people who can be trusted in their words, actions, and activities.

Based on the results of the interviews above, it can be concluded that individuals who have good self-control should be able to regulate their behavior in a more positive direction, regulate their behavior, and make wise decisions. However, if the individual cannot control behavior, it will make it challenging to regulate their behavior and make decisions so that violence, intimidation, and emotional behavior such as cyberbullying can occur.

\section{Literature Review}

Research conducted by Risyana [22] demonstrated a relationship between emotion regulation and cyberbullying behavior in adolescents. Research conducted by Sulistiawati, Amalia, and Rahma[23] on students aged 18-24 years who are social media users found that the lower the need for affection, the more the emergence of cyberbullying behavior and vice versa. Fakthurrohman [24] conducted previous research revealing a significant unidirectional relationship between loneliness and cyberbullying behavior in adolescents at Dharma Wanita High School.

Emotion regulation helps individuals manage, regulate emotions or feelings, and control emotions so that they are not excessive [25]. Unfulfilled emotional needs, including the need for affection (love and affection), lead individuals to feel hurt and take revenge, failing to control their emotions. Hence, they are encouraged to carry out cyber bullying [26]. Individuals are lonely because they feel they have no one (Rice in Tiska,[27]). Loneliness will lead to escape behaviors to get recognition, which is cyberbullying behavior [28]. Regulation, the need for affection, and loneliness relate to internal factors or the individual, impacting cyberbullying behavior.

There is another variable that is an internal factor within the individual, namely selfcontrol. Based on previous studies conducted by Zakiya [29], it was found that the 
effective contribution of self-control to cyberbullying intentions was $50.9 \%$ in adolescents aged 13-18 years in Palembang City. Another study conducted by Fadhilah, Rahma, and Narastri (2020) found an effective contribution of self-control to cyberbullying by $15.3 \%$ in adolescents aged 15-18 years in Palembang City. It is known that the two studies on self-control and cyberbullying above were conducted on urban adolescents, with a far different amount of effective contribution of self-control against cyberbullying, i.e., $50.9 \%$ and $15.9 \%$.

\section{Method}

The study instruments were a Cyberbullying Scale developed by the researchers based on cyberbullying behavioral forms according to Willard [14] and a Self-Control Scale developed by the researchers based on self-control aspects of Averill[21]. These study instruments utilized four answer categories: strongly agree, agree, disagree, strongly disagree. The use of four answer alternatives aimed to sound their opinions and not take the neutral side.

The trial was conducted on 30 subjects with similar characteristics similar to the study samples, i.e., adolescents aged 15-18 years who are active users of social media and are not from Private High School X in Bogor. Validity testing in this study utilized evidence based on test content on expert lecturers. The main purpose of this process was to obtain respondent validation of the Self-Control Scale and the Cyberbullying Scale items. Based on the trials, 26 items out of 42 overall items were valid on the cyberbullying scale consisting of nine favorable items and 16 unfavorable items. Meanwhile, there were 22 valid items out of 40 items on the overall self-control scale consisting of 11 favorable items and 11 unfavorable items. Reliability was calculated using Cronbach's Alpha. The reliability of the cyberbullying behavior scale is 0.873 . The reliability of the self-control scale is 0.853 . Reliability is said to be good if it has a Cronbach's Alpha value $>0.60$, then it can be concluded that the instrument concerned is declared reliable [30].

The data analysis techniques used in this study were Descriptive Analysis and Pearson Product Moment Correlation Analysis. Descriptive analysis was used to describe the level of self-control and cyberbullying behavior at Private High School X in Bogor. Pearson Product Moment Correlation Analysis consists of normality, linearity, and hypothesis tests with the help of the IBM SPSS Statistics 25 program. A normality test was employed to determine whether the two variables have a normal distribution. Normality test was performed using the One-Sample Kolmogorov-Smirnov test. The distribution is declared normal if the significance value is greater than 0.05 (Sign. > 0.05). A linearity test was 
utilized to determine whether the variables of self-control and cyberbullying behavior have a linear correlation or not. The linearity test was carried out using a test for linearity. Two variables are said to have a linear correlation if the linearity significance level is $>0.05$. The hypothesis test aimed to prove a correlation between the independent variable (self-control) and the dependent variable (cyberbullying behavior). In examining the hypothesis in this study, product-moment correlation analysis was used with a significance value of 0.05 . The two variables are said to have a positive correlation if they have a significance value (p) less than $0.05(p<0.05)$. The size of the correlation coefficient indicates the strength of the correlation formed from the two variables.

\section{Result and Discussion}

\subsection{Result}

The research subjects were 95 private high school students in Bogor City who were in online learning activities. The results revealed that 36 subjects (37.9\%) were male, and 66 (62.1\%) were female. Based on grade level, 44 subjects (46.3\%) were in class X, 27 (28.4\%) were in class XI, and 24 (25.3\%) were in class XII. Based on the age level, three subjects aged 14 years (3.2\%), subjects aged 15 and 16 years amounted to 33 subjects (34.7\%), subjects aged 17 years amounted to 25 people (26.3\%), and subjects aged 18 years amounted to one person with a percentage of $1 \%$. The average subject was 15-17 years old. The subject characteristics were based on the number of social media users from 95 subjects. There were 22 subjects (23.2\%) having one social media, seven subjects $(7.4 \%)$ having two social media, 13 subjects (13.7\%) having three social media, 18 subjects having four social media, 22 subjects ( $23.2 \%$ ) having five social media, ten subjects (10.5\%) having six social media, and three subjects (3.2\%) having seven social media.

Based on the results of the data analysis on the self-control scale, 71 students $(74.7 \%)$ had high self-control, 24 students with a percentage of $25.3 \%$ had moderate levels of self-control, and 0 students had low levels of self-control. From these data, the level of self-control of the subject was mostly high, with a percentage of $74.7 \%$. Moreover, based on the data analysis results on the cyberbullying behavior scale, 81 students with a percentage of $85.3 \%$ had a low level of cyberbullying behavior, 14 students with a percentage of $14.7 \%$ had a moderate level of cyberbullying behavior, and 0 students had a high level of cyberbullying behavior. From these data, the subject's cyberbullying behavior was mostly low, with a percentage of $85.3 \%$. 
The normality test result was 0.2 , over the significance of 0.05 or $p>0.05$. Hence, it concludes that the data from self-control $(X)$ and cyberbullying behavior variables were normally distributed. Based on the linearity test, it is known that the linearity test result was 0.459 , over 0.05 or Sign. $>0.05$. Therefore, the correlation between self-control $(X)$ and cyberbullying behavior variables was linear. Based on the hypothesis test, it is revealed that the significance was 0.00 , smaller than $0.05(p<0.05)$, meaning that $\mathrm{HO}$ was rejected and $\mathrm{H} 1$ was accepted. Thus, there was a significant correlation between variable $X$ (self-control) and variable $Y$ (cyberbullying behavior). Then, the calculated $r$ was -0.465 , indicating that variables $X$ and $Y$ were negatively related or not in the same direction. If variable $X$ is high, variable $Y$ is low, and vice versa. To see the strengths and weaknesses of the correlation, the researcher employed the correlation coefficient interpretation guideline from Sugiyono (2017). The calculated r-value of 0.465 is categorized as a medium interval. Hence, it can be seen that the correlation between variables $X$ and $Y$ in this study is moderate.

\subsection{Discussion}

Based on the analysis results on the cyberbullying behavior scale, it was found that most of the students in Private High School X in Bogor City had a low level of cyberbullying behavior. Individuals with low levels of cyberbullying indicate that individuals have high empathy, understand ethics, and use social media well because they are less likely to harass and intimidate others on social media. Meanwhile, individuals with high levels of cyberbullying have low empathy, lack of understanding of ethics, and misuse social media, such as making fun of others and committing harassment. Cyberbullying behavior has a high risk of being involved in juvenile delinquency, crime, and alcohol abuse [15].

The level of cyberbullying behavior is influenced by internal and external factors[31]. Internal factors are associated with the personality characteristics of each individual. Meanwhile, external factors are related to technological developments, which increasingly provide convenience in using social media, especially for teenagers.

Based on the analysis results on the self-control scale, it was discovered that most students in Private High School X in Bogor City had a high level of self-control. Following Averill's [21] opinion, individuals with high self-control can control the situation, modify an unpleasant ability where the individual can prevent, stay away or stop things that will happen, inhibits their activities in the sense that their environment does not control them. Also, individuals with good self-control have cognitive control in which they can 
process unwanted information to reduce pressure by anticipating the situation through objective consideration and assessing and interpreting a situation from the positive side. Individuals with good self-control also have good decision control to choose and determine based on what they agree or believe.

According to Ghufron and Risnawati [32], individuals with high self-control will behave under the demands of social situations to become more flexible and open individuals. Meanwhile, individuals with a poor level of self-control will lead to consequences that can harm others and themselves, such as difficulty controlling situations and careless decision making, causing them to act without considering the possible consequences.

Differences in self-control can be affected by internal and external factors [33]. The internal factor in question is age. The older the individual, the better their ability to control themself due to maturity and differentiate between good and bad. In this study, the majority of students aged 15 years (34.7\%), 16 years (34.7\%), and 17 years (26\%), 14 years $(3.2 \%)$, and 18 years (1\%) were included in the category of teenagers. Adolescence is a period of transition from children to adults. At this time, adolescents will begin becoming individuals who can conduct behavioral assessments independently by knowing the consequences [34]. According to Hurlock [33], the older the individual, the better their ability to control themself due to maturity. They can also differentiate between good and bad. External factors can also affect self-control in the family environment and the environment around the individual. According to Desmita [35], adolescents with secure attachments such as comfortable and harmonious correlations with their parents can help with social competence and good emotional well-being. Then environmental factors around individuals such as peers can also affect self-control in adolescents. During adolescence, most of their time is spent connecting with peers.

One of the developmental tasks of adolescents aged 12-18 years, according to Havighurst in Monks et al. [34], is resolving their identity crisis. The more successful the individual in overcoming the crisis, the healthier his development [1]. However, individuals who fail to overcome the crisis will significantly endanger their future since it is primarily determined by the resolution of the crisis [35]. One of the achievements of resolving the identity crisis is that adolescents can make important decisions [1]. Decision-making ability is related to one's self-control. Self-control is emotional control, an internal drive that enables individuals to make decisions and take practical actions following ideal standards, moral values, and social expectations [36].

Adolescents failing to complete critical identity will develop problematic behaviors that are considered deviant, one of which is juvenile delinquency such as cyberbullying behavior. Santrock[1] explained that one of the factors affecting juvenile delinquency 
is self-control. Therefore, good self-control can reduce the tendency of teenagers to behave in problems such as cyberbullying behavior.

The Pearson Product Moment Correlation test analysis discovered a significant correlation between self-control and cyberbullying behavior at Private High School $X$ in Bogor City. The strength of the correlation between the two variables was moderate. The correlation's direction between the two variables in this study was negative linear. It indicates that the higher the level of self-control, the lower the level of cyberbullying behavior and vice versa. Several studies are in line with the study results, i.e., a study by Fadhilah, Rahma, and Narastri). The results showed a significant negative correlation between self-control and cyberbullying in adolescents aged 15-18 years. Furthermore, Hidayat [19] conducted a similar study demonstrating a significant negative relationship between self-control and the intention to carry out cyberbullying in early adulthood. A study by Haswinar [37] concerned the relationship between self-control and cyberbullying in online game users. It was found that there was a very significant negative relationship between the variables of self-control and cyberbullying in online game users.

Preliminary data from interviews conducted by researchers in March 2021 to five students of grade XI of Private High School X in Bogor City concerning cyberbullying was in line with the study results. Disa (in Satalina,[18]) argued that several factors could influence cyberbullying behavior in adolescents: the impact of perpetrators who have experienced traditional bullying. It follows the results of interviews with researchers that bullying behavior in schools continues to cyberbullying behavior on social media. It was observed that the five interviewed students were grade $\mathrm{XI}$ students of Private High School X in Bogor City (in June 2021, they were upgraded to class XII) who still experienced offline/face-to-face learning during grade $X$ before ultimately doing online learning. Hence, students recognized and had the potential to do bullying behavior at school. It might be a factor in the emergence of cyberbullying behavior on social media. Meanwhile, the samples in this study were grades $X, X I$, and $X I I$, where grades $X$ and $X I$ did not experience offline schooling. Thus, students of grades $X$ and $X I$ did not know that such bullying behaviors may occur in school. Therefore, the study results demonstrated a significant non-unidirectional correlation between self-control and cyberbullying behavior at Private High School $\mathrm{X}$ in Bogor City, accepting the hypothesis, i.e., a correlation between self-control and cyberbullying behavior in Private High School X students in Bogor City. If the level of self-control in Private High School $X$ in Bogor City is high, then the level of cyberbullying behavior in Private High School $X$ in Bogor City will be low and vice versa. 


\section{Acknowledge, Funding \& Ethics Policies}

The researchers express gratitude to supervising lecturers in this study and to various parties who have supported the continuity of this study.

\section{References}

[1] Santrock JW. Life-span development. Boston:McGraw-Hill;2002.

[2] Steinberg L, Silk JS. Parenting adolescents.Mahwah State: Lawrence Erlbraum Associates; 2002.

[3] Yusuf S. Psikologi perkembangan anak dan remaja. Bandung: PT Remaja Rosdakarya; 2009.

[4] Coloroso B. Stop bullying (memutus rantai kekerasan anak dari prasekolah hingga $\mathrm{SMU})$.

Jakarta: Ikrar Mandiri Abadi; 2007.

[5] APJII. Laporan survei internet APJII 2019 - 2020 (Q2). Jakarta:Indonesia Internet Serviice Provider Association;2020.

[6] Fitri S. Dampak positif dan negatif sosial media terhadap perubahan sosial anak: Dampak positif dan negatif sosial media terhadap perubahan sosial anak. Naturalistic: Jurnal Kajian Penelitian Pendidikan dan Pembelajaran. 2017;1(2):118-123.

[7] Akram W, Kumar R. A study on positive and negative effects of social media on society. International Journal of Computer Sciences and Engineering. 2017;5(10):347354.

[8] Sticca F, Perren S. Is cyberbullying worse than traditional bullying? Examining the differential roles of medium, publicity, and anonymity for the perceived severity of bullying. Journal of Youth and Adolescence. 2013;42(5):739-750.

[9] Zain FM . 4 Anak Pelaku Perundungan di Cilacap Jadi Tersangka, Pelaku dan Korban Ternyata Satu SMP. Kompas;2021. Available from https://regional.kompas.com/read/2021/01/07/12262611/4-anak-pelaku-perundungandi-cilacap-jadi-tersangka-pelaku-dan-korban?page=all.

[10] Lova Chntia. Aksi Bullying Pelajar di Kabupaten Bekasi Dipicu Saling Ejek di Medsos . Kompas;2020. Available form : https://megapolitan.kompas.com/read/2020/07/28/23322431/aksi-bullying-pelajardi-kabupaten-bekasi-dipicu-saling-ejek-di-medsos?page=all. 
[11] Saudale V. Bocah Korban Perundungan di Bogor Dimediasi Polisi. Beritasatu;2021. Available from : https://www.beritasatu.com/megapolitan/764199/bocah-korbanperundungan-di-bogor-dimediasi-polisi

[12] Sriwahyuni N. Hubungan antara kontrol diri dengan kenakalan remaja di kelurahan mabar hilir. Psikologi Konseling. 2017;10(1):60-74.

[13] Malihah Z, Alfiasari A. Perilaku cyberbullying pada remaja dan kaitannya dengan kontrol diri dan komunikasi orang tua. Jurnal Ilmu Keluarga dan Konsumen.2018; 11(2): 145-156. https://doi.org/10.24156/jikk.2018.11.2.145

[14] Willard N. Educator's guide to cyberbullying addressing the harm caused by online social cruelty.Scientific Research. 2005. Available from : http://cyberbully.org

[15] Syah R, Hermawati I. Upaya pencegahan kasus cyberbullying bagi remaja pengguna media sosial di indonesia. Jurnal Penelitian Kesejahteraan Sosial. 2018;17(2):131-146.

[16] Rudi R. Informasi perihal bullying: Tindakan cyberbullying. Jakarta: Rajawali Pers; 2010.

[17] Pandie MM, Weismann I. Pengaruh cyberbullying di media sosial terhadap perilaku reaktif sebagai pelaku maupun sebagai korban cyberbullying pada Siswa Kristen SMP Nasional Makassar. Jurnal Jaffray. 2016;14(1):43-62.

[18] Satalina D. Kecenderungan perilaku cyberbullying ditinjau dari tipe kepribadian ekstrovert dan introvert. Jurnal IImiah Psikologi Terapan. 2014;2(2):294-310.

[19] Hidayat H. Hubungan kontrol diri dengan intensi melakukan cyberbullying. Malang: Muhammadiyah University of Malang;2017.

[20] Dewi HA, Suryani S, Sriati A. Faktor faktor yang mempengaruhi cyberbullying pada remaja: A systematic review. Journal of Nursing Care. 2020;3(2).128-141.

[21] Averill JR. Personal kontrol over aversive stimuli and its relationship to stress. Psychological Bulletin. 1973;80(4):286.

[22] Risyana D. Relationship between emotion regulation adn cyberbullying behavior in adolescents. Riau: State Islamic University of Sutan Syarif Kasim Riau;2019.

[23] Sulistiyawati Y, Amalia R, Rahma RA 2021, 'Hubungan kebutuhan afeksi terhadap perilaku cyberbullying pada mahasiswa', Annual Conference of Seminar Nasional dan Call Paper Mahasiswa (SENACAM) ,Malang, Indonesia, 10 April 2021. http://conference.um.ac.id/index.php/psi/article/view/1237

[24] Fatkhurrohman AY. Hubungan antara kesepian dengan perilaku cyberbullying pada remaja. Surabaya:State Islamic University of Sunan Ampel Surabaya;2020.

[25] Garnefski N, Kraaij V, Spinhoven P. Negative life events, cognitive emotion regulation and emotional problems. Personality and Individual Differences. 2001;30(8):1311-1327. https://doi.org/10.1016/S0191-8869(00)00113-6 
[26] Persada SP. Fenomena perilaku cyberbullying di dalam jejaring sosial twitter. Semarang: Diponegoro University;2014.

[27] Tiska SY. Hubungan antara kesepian dan kebutuhan afiliasi pada remaja akhir yang senang clubbing. Jurnal Hubungan antara Kesepian dan Kebutuhan. Jakarta: Gunadarma University.

[28] Caplan, SE. A theory of problematic internet use and psychosocial well-being. Communication Research. 2003;30(6):625-648.

[29] Zakiya B. Peran kontrol diri terhadap intensi melakukan melakukan cyberbullying pada remaja di kota palembang. Palembang:Sriwijaya University;2019.

[30] Sujarweni W. Metodologi penelitian: lengkap, praktis, dan mudah dipahami. Yogyakarta: PT Pustaka Baru;2014.

[31] Jalal NM, Idris M, Muliana M. Faktor-faktor cyberbullying pada remaja. IKRA-ITH HUMANIORA: Jurnal Sosial dan Humaniora. 2021;5(2):1-9.

[32] Ghufron MN, Risnawita SR. Teori-teori psikologi. Yogyakarta: Ar-Ruzz Media;2011.

[33] Hurlock EB. Psikologi perkembangan. Jakarta: Erlangga; 1980.

[34] Monks FJ, Knoers AMP, Haditono SR. Psikologi perkembangan: Pengantar dalam berbagai bagiannya. Yogyakarta: Gajah Mada University Press; 2001.

[35] Desmita D. Psikologi perkembangan. Bandung: Remaja Rosdakarya; 2005.

[36] Tangney JP, Baumeister RF, Boone AL. High self囚control predicts good adjustment, less pathology, better grades, and interpersonal success. Journal of Personality. 2004;72(2):271-324.

[37] Migunani HC. Hubungan antara kontrol diri dengan cyberbullying pada remaja pengguna game online. Surakarta:Muhammadiyah University of Surakarta;2021. 